\title{
Guanidinoacetate Amidinohydrolase from a Flavobacterium Purification, Crystallization and Properties
}

\author{
Takamitsu Yorifuji, Nobuo Komaki, Kiyoshi OKeTani \\ and Etsuzo ENTANI \\ Department of Agricultural Chemistry, Shinshu University, \\ Ina-shi, Nagano-ken 396, Japan
}

Received July 6, 1978

\begin{abstract}
Guanidinoacetate amidinohydrolase (glycocyaminase, EC 3.5.3.2) was purified 148-fold and crystallized from Flavobacterium sp. GE-1 grown in a medium supplemented with guanidinoacetate. The molecular weight of the enzyme was estimated to be about 281,000 daltons by a gel electrophoretic procedure. SDS-polyacrylamide electrophoresis showed a single component of subunit with an estimated molecular weight of 70,000 daltons, suggesting that the enzyme is composed of four subunits identical in molecular weight. These values are significantly distinct from those of an analogous enzyme from a Pseudomonas reported by us previously. The native enzyme was active without added divalent metals. Incubation of the enzyme with 1,10-phenanthroline at an elevated temperature $\left(50^{\circ} \mathrm{C}\right)$ resulted in almost complete inactivation. The activity of the inactivated enzyme was restored by incubation with $\mathrm{Zn}^{2+}$ or $\mathrm{Co}^{2+}$ at $50^{\circ} \mathrm{C}$; the former cation was more effective. The enzyme was optimally active at $\mathrm{pH} 8.0 \sim 8.5$. The apparent $\mathrm{Km}$ value for guanidinoacetate was $15 \mathrm{~mm}$. 3-Guanidinopropionate and 4-guanidinobutyrate were hydrolyzed $19 \%$ and $9 \%$, respectively, as fast as guanidinoacetate. PCMB was a potent inbibitor of the enzyme. The properties of the Flavobacterium enzyme were compared with those of the analogous Pseudomonas enzyme.
\end{abstract}

Guanidinoacetate amidinohydrolase (glycocyaminase, EC 3.5.3.2) catalyzes the hydrolytic cleavage of guanidinoacetate to glycine and urea. We have purified two distinct guanidinoacetate amidinohydrolase from bacteria. In previous papers $^{1,2)}$ we reported the properties of crystalline guanidinoacetate amidinohydrolase from Pseudomonas sp. ATCC 14676, which required $\mathrm{Mn}^{2+}$ for the activity. The present paper describes the crystallization and properties of the other amidinohydrolase produced by a strain of Flavobacterium. The native enzyme did not require any divalent cations for the activity.

\section{MATERIALS AND METHODS}

Organism. Flavobacterium sp. GE-1 was isolated from garden soil with a medium which contained guanidinoacetate as the sole nitrogen source. The bacterial

Abbreviations: TCA, trichloroacetic acid; SDS, sodium dodecyl sulfate; EDTA, (ethylenedinitrilo) tetraacetate; DTNB, 5, 5'-dithiobis ( $p$-nitrobenzoate); PCMB, $p$-(chloromercuri)benzoate. strain was tentatively assigned to the genus Flavobacterium on the basis of the following observations: cells gram-negative, short rods without flagella and nonmotile; colonies translucent, smooth, light yellow waterinsoluble pigmentation, and no swarming on agar media; strictly aerobic and growth temperature optimum below $30^{\circ} \mathrm{C}$; nitrate reducing, catalase and oxidase positive.

Chemicals. 3-Guanidinopropionic acid was purchased from Calbiochem, 4-guanidinobutyrate from Sigma, creatine and agmatine from Merck, and guanylurea and $\mathrm{N}$-amidinoalanine from Eastman. DEAEcellulose was the product of Whatman (DE-23). Sephadex G-25 and Sephadex G-200 were from Pharmacia. Horse heart cytochrome $\mathrm{C}$, bovine pancreas chymotrypsinogen $\mathrm{A}$, beef liver catalase and ferritin were from Boehringer Mannheim. Ovalbumin and bovine serum albumin were from Sigma. Other chemicals were of reagent grade and purchased from Nakarai Chemicals.

Growth of cells. The basal medium for cultivation of Flavobacterium GE-1 contained $0.5 \%$ glycerol, $0.2 \%$ $\mathrm{NaCl}, 0.1 \% \mathrm{~K}_{2} \mathrm{HPO}_{4}, 0.02 \% \mathrm{MgSO}_{4} \cdot 7 \mathrm{H}_{2} \mathrm{O}$ and $0.05 \%$ yeast extract ( $\mathrm{pH} 7.5$ ). The inoculum culture was grown at $30^{\circ} \mathrm{C}$ for $14 \mathrm{hr}$ in 2-liter shaking flasks which contained $500 \mathrm{ml}$ of basal medium supplemented with $0.4 \%$ 
peptone. For cultivation of cells used in enzyme preparation, two inoculum cultures were prepared and transferred into 15 liters of basal medium supplemented with $0.04 \%$ guanidinoacetic acid. Incubation was carried out at $30^{\circ} \mathrm{C}$ for $6 \sim 10 \mathrm{hr}$ under aeration with a Hitachi SH-5S air compressor (40 liters per min) through a sterilized air filter. When guanidinoacetate disappeared from the medium the cells were harvested by continuous centrifugation at $12,000 \times g$ and washed twice with $0.85 \% \mathrm{NaCl}$.

Enzyme assay. As the native guanidinoacetate amidinohydrolase from Flavobacterium GE-1 did not require divalent cations for maximal activity, the enzyme was assayed without adding divalent metal salts. The assay solution contained, in $1.0 \mathrm{ml}, 0.01 \sim 0.1$ unit of the amidinohydrolase, $100 \mathrm{~mm}$ Tris- $\mathrm{HCl}$ buffer, $\mathrm{pH} 8.0$, and $25 \mathrm{~mm}$ guanidinoacetic acid. After incubation at $30^{\circ} \mathrm{C}$ for $30 \mathrm{~min}, 1.0 \mathrm{ml}$ of $12.5 \% \mathrm{TCA}$ was added into the solution to terminate the reaction. The precipitate was centrifuged off and the supernatant was applied to urea determination.

Analytical methods. Guanidinoacetate and other guanidino compounds were determined by a colorimetric procedure using $\alpha$-naphthol and diacetyl. ${ }^{3)}$ Urea was determined by a simplified procedure ${ }^{4)}$ of $\mathrm{Ar}$ chibald. ${ }^{\text {5) }}$ Protein concentration in crude or slightly purified extract was measured according to the method of Lowry et al ${ }^{\left.{ }^{B}\right)}$ with bovine serum albumin as standard, using an extinction coefficient $E(1 \%)$ at $280 \mathrm{~nm}$ of 6.7. With more extensively purified preparation, protein concentration was estimated from absorbance at $280 \mathrm{~nm}$ using $E(1 \%)$ values of 10 for enzyme of 10 to 100 units/mg and 8.4 for crystalline preparations. The latter value was determined by counting Rayleigh fringes observed with interference optics on centrifugation of crystalline enzyme in a synthetic boundary cell. $^{7}$ A value of specific refractive increment for protein of $1.874 \mathrm{dl} / \mathrm{g}^{8)}$ was used for the calculation.

\section{RESULTS}

\section{Purification of enzyme}

All manipulations were at $0^{\circ} \sim 5^{\circ} \mathrm{C}$ unless stated otherwise. Frozen cell paste $(500 \mathrm{~g}$ wet weight) was thawed in 2 liters of $20 \mathrm{~mm}$ potassium phosphate buffer, $\mathrm{pH}$ 8.0. The suspension was sonically treated in $300-\mathrm{ml}$ batches for $90 \mathrm{~min}$ at $0^{\circ} \sim 10^{\circ} \mathrm{C}$ with Kaijo Denki $19 \mathrm{kHz}$ sonic disintegrator, maintaining the $\mathrm{pH}$ at about 8.0 with $3 \mathrm{~N}$ ammonium hydroxide. The sonicate was centrifuged for $30 \mathrm{~min}$ at 10,000 $\times g$. The supernatant $(1400 \mathrm{ml})$ retained as the crude extract was brought to $30 \%$ satura- tion by adding $293 \mathrm{~g}$ of solid ammonium sulfate with mechanical stirring; the $\mathrm{pH}$ was maintained at about 8.0 with $3 \mathrm{~N}$ ammonium hydroxide. The mixture was stored overnight at $4^{\circ} \mathrm{C}$ and the precipitate formed was removed by centrifugation. To the supernatant (1460 $\mathrm{ml}$ ) was added $189 \mathrm{~g}$ of ammonium sulfate to $55 \%$ saturation. After $2 \mathrm{hr}$ of stirring, the precipitate was collected by centrifugation and dissolved in $100 \mathrm{ml}$ of $10 \mathrm{~mm}$ potassium phosphate buffer, $\mathrm{pH} 8.0$. The enzyme was dialyzed against three changes of 2 liters each of $10 \mathrm{~mm}$ potassium phosphate buffer, $\mathrm{pH}$ 7.2 , and then applied to a DEAE-cellulose column $(4 \times 29 \mathrm{~cm})$ equilibrated with the dialysis buffer. The column was washed with $1000 \mathrm{ml}$ of $10 \mathrm{~mm}$ potassium phosphate buffer, $\mathrm{pH} 7.2$, supplemented with $0.3 \mathrm{M} \mathrm{KCl}$; then the enzyme was eluted with the buffer containing $0.4 \mathrm{M} \mathrm{KCl}$ at a flow rate of $65 \mathrm{ml}$ per hr. Active fractions were pooled $(300 \mathrm{ml})$ and concentrated by adding $142 \mathrm{~g}$ of ammonium sulfate to $70 \%$ saturation, maintaining the $\mathrm{pH}$ at $7.5 \sim 8.0$ with $3 \mathrm{~N}$ ammonium hydroxide. The precipitate formed during overnight storage at $4^{\circ} \mathrm{C}$ was collected by centrifugation and dissolved in $5 \mathrm{ml}$ of $10 \mathrm{~mm}$ potassium phosphate buffer, pH 8.0 (DEAE-cellulose

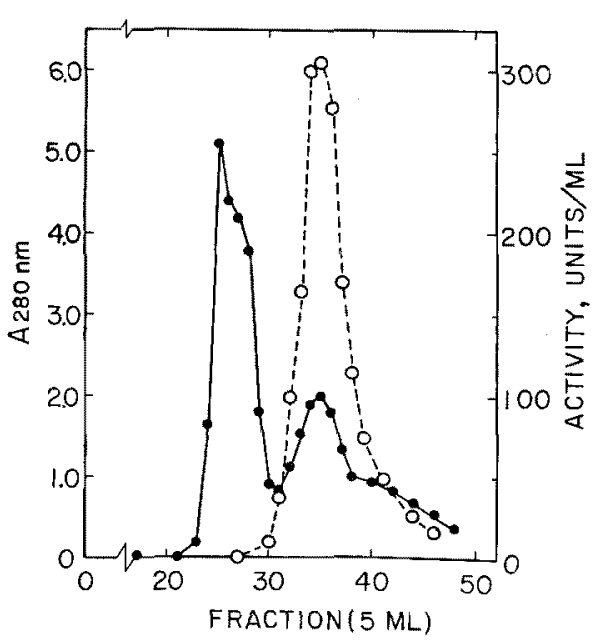

FIG. 1. Chromatography of the Enzyme on a Sephadex G-200 Column.

The experimental conditions are given in the text. Absorbance at $280 \mathrm{~nm}(\bullet)$; amidinohydrolase activity (O). 


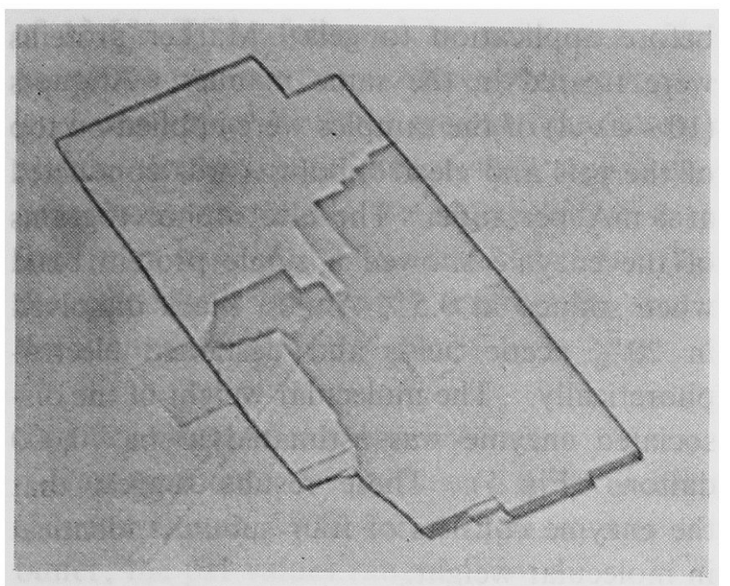

FIG. 2. Crystalline Guanidinoacetate Amidinohydrolase from Flavobacterium GE-1. $\times 600$.

fraction). The fraction was applied to a column of Sephadex G-200 $(2 \times 93 \mathrm{~cm})$ which had been equilibrated with $10 \mathrm{~mm}$ potassium phosphate buffer, $\mathrm{pH}$ 8.0. The enzyme was eluted with the same buffer at hydrodynamic pressure of $10 \mathrm{~cm}$. The elution pattern is shown in Fig. 1. Fractions 34, 35 and 36 were pooled (Fraction $\mathrm{A}$ ) and other active fractions of lower specific activities (fractions 32, 33, 37 and 38) were also pooled (Fraction B). Both fractions were concentrated in a collodion bag to about $5 \mathrm{ml}$. To Fraction $\mathrm{A}$ was added ammonium sulfate until a faint turbidity was obtained. The crystalline enzyme precipitated after the solution was stored overnight in a refrigerator. A smaller amount of crystalline enzyme was obtained from Fraction B by adding ammonium sulfate and a bit of the

Table I. Summary of Enzyme Purification

\begin{tabular}{|c|c|c|c|c|}
\hline Fraction & $\begin{array}{l}\text { Protein } \\
\text { (mg) }\end{array}$ & $\begin{array}{l}\text { Total } \\
\text { activity } \\
\text { (units) }\end{array}$ & $\begin{array}{c}\text { Specific } \\
\text { activity } \\
\text { (units/ } \\
\text { mg) }\end{array}$ & $\begin{array}{c}\text { Yield } \\
(\%)\end{array}$ \\
\hline Crude extract & $16,900^{a}$ & 21,600 & 1.28 & 100 \\
\hline $\begin{array}{l}\text { Ammonium } \\
\text { sulfate } \\
(35 \sim 55 \%)\end{array}$ & $2,860^{a}$ & 17,200 & 6.00 & 80 \\
\hline DEAE-cellulose & $273^{b}$ & 12,200 & 44.7 & 56 \\
\hline Sephadex G-200 & $28^{b}$ & 4,430 & 158 & 21 \\
\hline Crystallization & $19^{c}$ & 3,610 & 190 & 17 \\
\hline
\end{tabular}

a Determined by the method of Lowry et al. ${ }^{6}$ )

$b$ Determined from $A_{280}$ and $E(1 \%)=10.0$

c Determined from $A_{280}$ and $E(1 \%)=8.4$. crystals from Fraction A. The crystals were colorless, thin plates as shown in Fig. 2. The purification procedure is summarized in Table $\mathrm{I}$.

\section{Purity and molecular weight}

Polyacrylamide gel electrophoresis of the enzyme was conducted by use of gels containing $6,7,8$ and $9 \%$ polyacrylamide and the Trisglycine pH 8.3 buffer system of Hedrick and Smith. ${ }^{9}$ ) As shown in Fig. 3, the crystalline

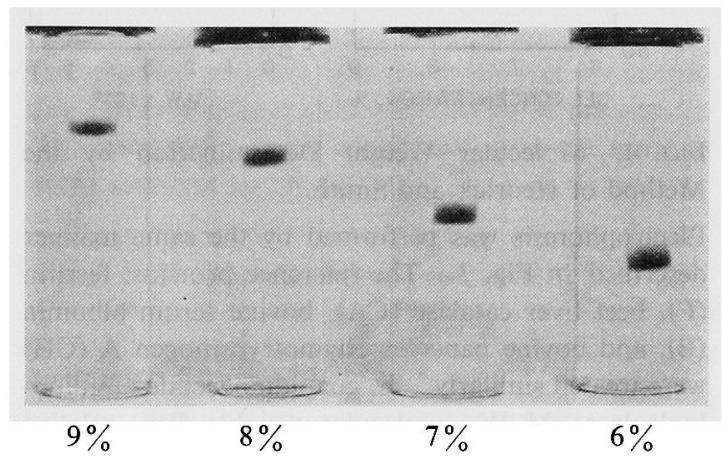

FIG. 3. Polyacrylamide Gel Electrophoresis of the Purified Enzyme.

Polyacrylamide gels at the indicated concentrations with a Bis: acrylamide monomer ratio of $1: 30$ were prepared according to Hedrick and Smith ${ }^{9)}$ using the pH 8.3 Tris-glycine buffer system. The sample consisted of $40 \mu 1$ of $10 \mathrm{~mm}$ potassium phosphate buffer, $\mathrm{pH} 8.0$, containing $60 \mu \mathrm{g}$ of the crystalline enzyme, $20 \mu 1$ of $50 \%$ glycerol, $20 \mu \mathrm{l}$ of $0.01 \%$ bromophenol blue and $20 \mu$ l of electrode buffer to a final volume of $100 \mu \mathrm{l}$. Aliquots $(50 \mu \mathrm{l})$ of the sample were directly applied to the small pore gels, and electrophoresis was conducted at a current of $2 \mathrm{~mA}$ per gel. Protein bands were stained with Amido Black.

enzyme showed a single protein band when stained with Amido Black. Two molecular weight determinations by the procedure of Hedrick and Smith $^{9)}$ gave values of 280,000 and 282,000 daltons; the average value was 281,000 daltons. The second experiment is summarized in Fig. 4.

\section{Subunit structure}

Subunit structure of the enzyme was examined by polyacrylamide gel electrophoresis with SDS according to Weber and Osborn. ${ }^{10}$ The gels contained $10 \%$ polyacrylamide and $0.1 \%$ SDS. The enzyme $(40 \mu \mathrm{g})$ was incubated 

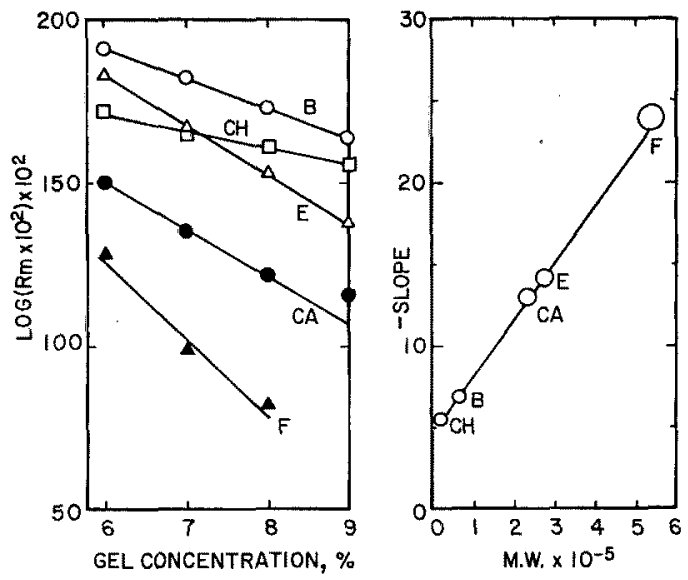

FIG, 4. Molecular Weight Determination by the Method of Hedrick and Smith. ${ }^{9)}$

Electrophoresis was performed by the same manner described in Fig. 3. The reference proteins, ferritin (F), beef liver catalase (CA), bovine serum albumin (B), and bovine pancreas chymotrypsinogen A $(\mathrm{CH})$ were treated similarly. E, guanidinoacetate amidinohydrolase; M. W., molecular weight; $\mathrm{Rm}$, relative mobility.

overnight at $25^{\circ} \mathrm{C}$ in $0.2 \mathrm{ml}$ of $10 \mathrm{~mm}$ potassium phosphate buffer, pH 7.2, which contained $25 \%$ glycrol, $1.0 \%$ SDS and $5 \% 2$-mercaptoethanol. The solution was then mixed with the same volume of $0.05 \%$ bromophenol blue

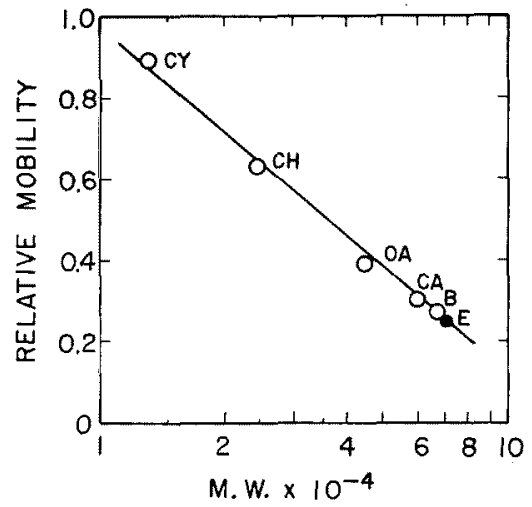

FIG. 5. Subunit Size Determination by SDS-polyacrylamide Disc Electrophoresis.

Electrophoresis was performed according to Weber and Osborn ${ }^{10)}$ with $10 \%$ polyacrylamide gels. The conditions are given in the text. The reference proteins were horse heart cytochrome $\mathrm{C}(\mathrm{CY})$, bovine pancreas chymotrypsinogen A $(\mathrm{CH})$, ovalbumin $(\mathrm{OA})$, beef liver catalase (CA) and bovine serum albumin (B). $\mathrm{E}$, guanidinoacetate amidinohydrolase; M. W., molecular weight. before application to gels. Marker proteins were treated in the same manner. Aliquots $(10 \sim 40 \mu 1)$ of the samples were applied on top of the gels and electrophoresis was conducted at $8 \mathrm{~mA}$ per tube. The electrophoretograms of the enzyme showed a single protein band when stained in $0.5 \%$ Amido Black dissolved in $20 \%$ acetic acid, and destained electrophoretically. The molecular weight of the dissociated enzyme was estimated to be 70,000 daltons (Fig. 5). These results suggest that the enzyme consists of four subunits identical in molecular weight.

\section{Absorption spectrum of enzyme}

The absorption spectrum was taken with a solution of the purified enzyme (167 $\mu \mathrm{g}$ per ml) in $10 \mathrm{~mm}$ potassium phosphate buffer, $\mathrm{pH} 8.0$. The enzyme exhibited a typical protein spectrum with an absorption maximum at $279 \mathrm{~nm}$ and a $A_{279} / A_{248}$ ratio of 1.56 .

\section{Stoichiometry and irreversibility of reaction}

The stoichiometry of the amidinohydrolase reaction was examined by use of a $10-\mathrm{ml}$ reaction mixture. The component were the same as those of the standard assay system. The mixture containing 3.0 units of the enzyme (106 units $/ \mathrm{mg}$ ) was incubated at $30^{\circ} \mathrm{C}$ for 180 min. Aliquots of $1.0 \mathrm{ml}$ were withdrawn at $30 \mathrm{~min}$ intervals and mixed with $1.0 \mathrm{ml}$ of $12.5 \% \mathrm{TCA}$, and then the solution was analyzed for guanidinoacetate, urea and glycine. Glycine was determined with ninhydrin by the procedure of Moore and Stein. ${ }^{11}$ Approximately equimolar amounts of urea and glycine were detected in each sample. The sum of the concentrations of guanidinoacetate and urea or glycine equaled $25.9 \pm 1.0 \mathrm{~mm}$ at each time point studied.

The reaction mixture for studies on reversibility of the reaction contained 5.3 units of the enzyme (106 units/mg), $100 \mathrm{~mm}$ potassium phosphate buffer, $\mathrm{pH} 8.0,25 \mathrm{~mm}$ glycine and $25 \mathrm{~mm}$ urea in $4.0 \mathrm{ml}$. The mixture was incubated at $30^{\circ} \mathrm{C}$. Aliquots of $1.0 \mathrm{ml}$ were withdrawn at $0,30,60$ and $100 \mathrm{~min}$ after initiation of reaction and mixed with $1.0 \mathrm{ml}$ each 
of $12.5 \% \mathrm{TCA}$, followed by colorimetry for guanidino compounds. Although the enzyme level was about 10 times greater than routine assays, neither guanidinoacetate nor other guanidino compounds were detected at each time point studied. These results indicate that the reaction is apparently irreversible under the conditions applied.

\section{Stability of enzyme on heat treatment}

Heat treatment was performed by incubating the enzyme at $55^{\circ} \mathrm{C}$ for $15 \mathrm{~min}$ in various buffer; the $\mathrm{pH}$ values ranged from 4.0 to 11.0 . Figure 6 shows that the enzyme was stable at $\mathrm{pH}$ from 5.5 to 10.0. A slight activation was observed in potassium phosphate buffer, $\mathrm{pH}$ $5.5 \sim 6.5$, and in Tris- $\mathrm{HCl}$ buffer, $\mathrm{pH} 8.0 \sim 8.5$.

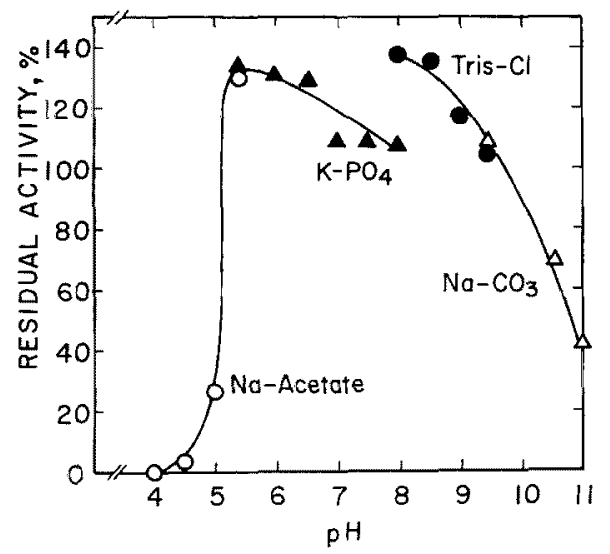

FiG. 6. Effects of $\mathrm{pH}$ and Buffers on the Stability of the Enzyme.

The incubation mixture contained, in $0.5 \mathrm{ml}, 40 \mathrm{~mm}$ concentration of the indicated buffer and $1.0 \mu \mathrm{g}$ of the enzyme (134 units $/ \mathrm{mg}$ ). After incubation at $55^{\circ} \mathrm{C}$ for $15 \mathrm{~min}$, a $0.2-\mathrm{ml}$ aliquot of the mixture was analyzed for amidinohydrolase activity.

\section{Effect of $p H$ on reaction rate}

Figure 7 shows that the enzyme is active at neutral to alkaline $\mathrm{pH}$; optimally active at pH 8.0 8.5. The activity at $\mathrm{pH} 7.0$ was about $70 \%$ of the maximal activity.

\section{Effect of metal chelators on enzyme}

Most amidinohydrolases require divalent metals for maximal activity. Although guanidinoacetate amidinohydrolase of Flavobacterium GE-1 did not require any divalent

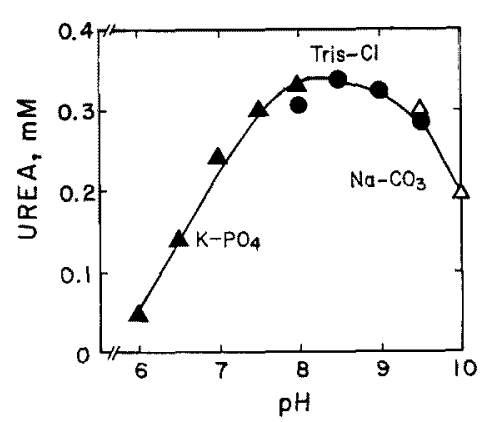

FIG. 7. Effects of pH and Buffers on the Enzyme Activity.

The reaction mixture contained $100 \mathrm{~mm}$ concentration of the indicated buffer and $0.8 \mu \mathrm{g}$ of the enzyme (134 units/mg). Other conditions were the same as in the standard assay.

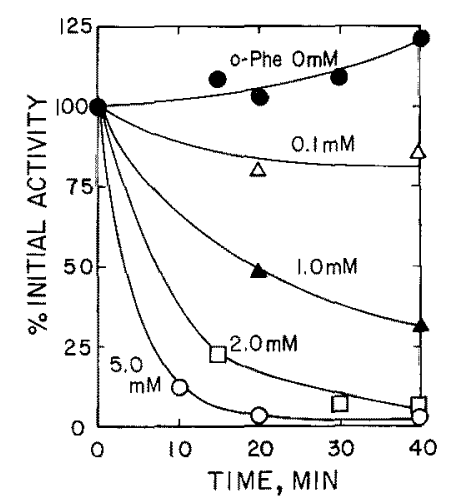

FIG. 8. Inactivation of the Enzyme with 1,10Phenanthroline.

The incubation mixture contained, in $2.0 \mathrm{ml}, 10 \mathrm{~mm}$ potassium phosphate buffer, $\mathrm{pH} 8.0$, various concentrations of 1, 10-phenanthroline and $5.3 \mu \mathrm{g}$ of the enzyme (106 units/mg). The mixture was incubated at $50^{\circ} \mathrm{C}$ for the time indicated, and then, a $0.2-\mathrm{ml}$ aliquot was assayed for amidinohydrolase activity. o-Phe, 1, 10-phenanthroline.

metals, it seemed possible that the enzyme contained tightly bound cations.

The enzyme was incubated with various metal chelators for $30 \mathrm{~min}$ at $30^{\circ} \mathrm{C}$ in $10 \mathrm{mv}$ potassium phosphate buffer, $\mathrm{pH} 8.0$. Witk $4.0 \mathrm{~mm} \mathrm{1,10-phenanthroline,} \mathrm{the} \mathrm{activity} \mathrm{de}$ creased by about $30 \%$ during incubation bu no decrease in activity was observed wit EDTA or 2,2'-dipyridyl. Incubation with 1,10 phenanthroline in Tris- $\mathrm{HCl}$ buffer, $\mathrm{pH} 9.0, \mathrm{O}$ in potassium phosphate buffer, $\mathrm{pH} 6.0$, gavı 
similar results. Complete inactivation was accomplished by incubating the enzyme at $50^{\circ} \mathrm{C}$ for $30 \mathrm{~min}$ in $10 \mathrm{mM}$ Tris- $\mathrm{HCl}$ buffer, $\mathrm{pH} 8.0$, in the presence of $5.0 \mathrm{mM}$ 1,10-phenanthroline (Fig. 8). No inactivation was observed with EDTA, 2,2'-dipyridyl or 8-hydroxyquinoline5 -sulfonate even at elevated temperature.

\section{Resolution of enzyme and effect of divalent metals on apoenzyme}

The apoenzyme was prepared as described in Fig. 9. When EDTA was omitted from the elution buffer used on Sephadex G-25 chromatography, the activity of the eluted enzyme was below $10 \%$ of the original activity. During storage for 8 days at $0^{\circ} \mathrm{C}$ without addition of divalent metals, the enzyme was reactivated to above $90 \%$ of original activity. Reactivation was also observed after incubation of the enzyme at $50^{\circ} \mathrm{C}$ for $90 \mathrm{~min}$. No reactivation was observed, however, after incubation at $50^{\circ} \mathrm{C}$ in the presence of $1.0 \mathrm{~mm}$ EDTA. Tests with diluted EDTA showed that the presence

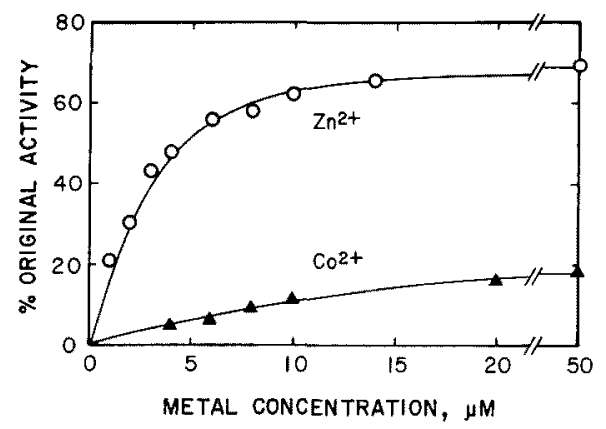

Fig. 9. Effect of $\mathrm{ZnCl}_{2}$ and $\mathrm{CoCl}_{2}$ on the 1,10Phenanthroline-treated Enzyme.

The preincubation mixture contained $640 \mu \mathrm{g}$ of the enzyme (150 units $/ \mathrm{mg}$ ), $10 \mathrm{~mm}$ Tris- $\mathrm{HCl}$ buffer, $\mathrm{pH}$ 8.0 , and $5.0 \mathrm{~mm} 1,10$-phenanthroline in $4.0 \mathrm{ml}$. After incubation at $50^{\circ} \mathrm{C}$ for $30 \mathrm{~min}$, the mixture was applied to a Sephadex G-25 column $(1.2 \times 25 \mathrm{~cm})$ equilibrated with $10 \mathrm{~mm}$ Tris-HCl buffer, $\mathrm{pH} 8.0$, containing $1.0 \mathrm{~mm}$ EDTA. The enzyme was eluted with the equilibration buffer, and the resultant enzyme was retained as 1, 10-phenanthroline-treated enzyme. The assay mixture contained $50 \mathrm{~mm}$ Tris- $\mathrm{HCl}$ buffer, $\mathrm{pH}$ 8.0, $1.0 \mu \mathrm{M}$ EDTA, various concentrations of $\mathrm{ZnCl}_{2}$ or $\mathrm{CoCl}_{2}, 0.17 \mu \mathrm{g}$ of the treated enzyme (3.0 units/ $\mathrm{mg}$ ) and $25 \mathrm{~mm}$ guanidinoacetate in $1.0 \mathrm{ml}$. Other conditions were the same as in the standard assay system. of $10 \mu \mathrm{M}$ EDTA was sufficient to prevent apparent spontaneous reactivation. These results indicate that the apoenzyme of the amidinohydrolase was formed by incubation with 1,10-phenanthroline and suggest that restoration of the activity of 1,10-phenanthrolinetreated enzyme in the absence of EDTA was due to the presence of unknown metals which activated the apoenzyme.

The effect of divalent cations on the apoenzyme was examined by adding various metal salts into the standard assay mixture at a concentration of $0.5 \mathrm{mM}$. $\mathrm{ZnCl}_{2}$ and $\mathrm{CoCl}_{2}$ were effective in activating the enzyme. The following metal salts had no activating effect: $\mathrm{CaCl}_{2}$ $\mathrm{CdCl}_{2}, \mathrm{CuSO}_{4}, \mathrm{FeCl}_{3}, \mathrm{HgCl}_{2}, \mathrm{MgSO}_{4}, \mathrm{MnCl}_{2}$ and $\mathrm{NiCl}_{2}$. Figure 9 shows the activity of the enzyme assayed immediately after the addition of various concentrations of $\mathrm{ZnCl}_{2}$ or $\mathrm{CoCl}_{2}$. The activity was restored to about $65 \%$ and $16 \%$ of original activity with $10 \mu \mathrm{M} \mathrm{ZnCl}_{2}$ and $20 \mu \mathrm{M} \mathrm{CoCl} l_{2}$, respectively. An almost complete reactivation was observed after incubation of the apoenzyme at $50^{\circ} \mathrm{C}$ for $10 \mathrm{~min}$ with 8.0 $\mu \mathrm{M} \mathrm{ZnCl}_{2}$ (Fig. 10). The highest activity at-

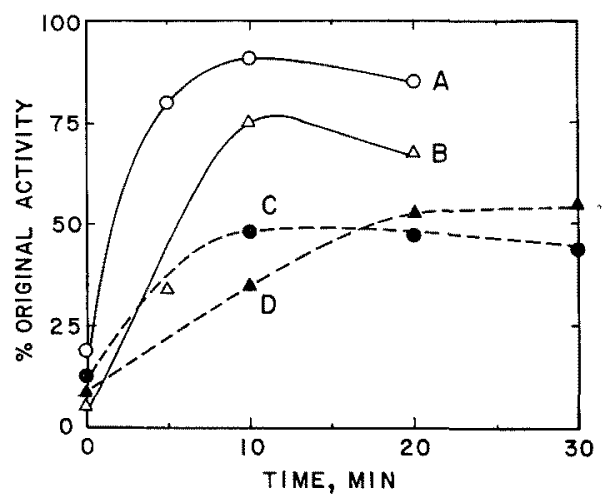

FIG. 10. Reactivation of the 1,10-Phenanthrolinetreated Enzyme with $\mathrm{ZnCl}_{2}$ or $\mathrm{CoCl}_{2}$.

The preincubation mixture contained, in $0.5 \mathrm{ml}$, $100 \mathrm{~mm}$ Tris-HCl buffer, pH 8.0, 2.0 $\mu \mathrm{M}$ EDTA, 0.17 $\mu \mathrm{g}$ of the 1,10-phenanthroline treated enzyme (3.0 units) $\mathrm{mg}$, original activity $150 \mathrm{units} / \mathrm{mg}$ ) and metal salt; $8.0 \mu \mathrm{M} \mathrm{ZnCl}_{2}$ (A), $4.0 \mu \mathrm{M} \mathrm{ZnCl}_{2}$ (B), $20 \mu \mathrm{M} \mathrm{CoCl}_{2}$ (C) or $8.0 \mu \mathrm{M} \mathrm{CoCl}_{2}$ (D). The mixture was incubated at $50^{\circ} \mathrm{C}$ for the time indicated. After cooling, $0.5 \mathrm{ml}$ of $50 \mathrm{~mm}$ guanidinoacetate was added to the mixture to initiate the enzyme reaction. Other conditions were the same as in the standard assay system. 
tained with $\mathrm{CoCl}_{2}$ was $66 \%$, which was obtained after incubation at $50^{\circ} \mathrm{C}$ for $20 \mathrm{~min}$ in the presence of $8.0 \mu \mathrm{M}$ of the salt.

\section{Substrate specificity}

The ability of the enzyme to hydrolyze various guanidino compounds was examined under conditions designed to detect the formation of urea at or above $1 \%$ of the rate observed with guanidinoacetate. Urea released from 3-guanidinopropionate and from 4-guanidinobutyrate was $19 \%$ and $9 \%$, respectively, of that released from guanidinoacetate. No urea was formed from $\mathrm{N}$-amidinoalanine, L-arginine, agmatine or creatine.

\section{$K m$ values}

The apparent $K m$ value of the enzyme for guanidinoacetate, determined under the standard conditions, except for the concentration of the substrate, was $15.0 \pm 2.0 \mathrm{~mm}$. The $\mathrm{Km}$ values for $\mathrm{Zn}^{2+}$ and $\mathrm{Co}^{2+}$ could not be determined because conditions for maximal activation of the apoenzyme with various cation concentrations were complex, as described earlier, e.g., in Fig. 10. The data shown in Fig. 9 and Fig. 10 suggest that the $K m$ values for $\mathrm{Zn}^{2+}$ and $\mathrm{Co}^{2+}$ are below $5 \mu \mathrm{M}$.

Table II. Effect of Various Compounds on ENZYME ACTIVITY

The indicated compound was added into the standard assay mixture $(1.0 \mathrm{ml})$ which contained $0.32 \mu \mathrm{g}$ of the enzyme (132 units $/ \mathrm{mg}$ ). Before addition of the substrate solution $(0.5 \mathrm{ml})$, the mixture was preincubated at $30^{\circ} \mathrm{C}$ for $3 \mathrm{~min}$.

\begin{tabular}{lcc} 
Compound & $\begin{array}{c}\text { Concentration } \\
(\mathrm{mM})\end{array}$ & $\begin{array}{c}\text { Inhibition } \\
(\%)\end{array}$ \\
\hline Creatine & 5.0 & 3 \\
N-Amidinoalanine & 5.0 & 4 \\
L-Arginine & 5.0 & 21 \\
Agmatine & 5.0 & 21 \\
Guanylurea & 5.0 & 5 \\
Taurine & 10.0 & 8 \\
B-Alanine & 10.0 & 10 \\
4-Aminobutyrate & 10.0 & 19 \\
5-Aminovalerate & 10.0 & 20 \\
6-Aminocaproate & 10.0 & 16 \\
Monoiodoacetate & 1.0 & 16 \\
N-Ethylmaleimide & 1.0 & 11 \\
DTNB & 1.0 & 25 \\
PCMB & 1.0 & 93 \\
\hline
\end{tabular}

\section{Inhibitors}

The effect of various compounds upon the hydrolysis rate of guanidinoacetate was tested and is shown in Table II. Creatine and Namidinoalanine, their structures are closely related to substrate guanidinoacetate, failed to affect the reaction rate. No appreciable influence was found with various $\omega$-amino acids tested. Among sulfhydryl reagents tested, PCMB was a potent inhibitor of the enzyme, while monoiodoacetic acid and N-ethylmaleimide exhibited almost no effect on the enzyme. DTNB inhibited the reaction slightly.

\section{DISCUSSION}

Guanidinoacetate amidinohydrolase was purified to homogeneity from Flavobacterium sp. GE-1 and crystallized. The native form of the enzyme was fully active without the addition of any divalent cation, in contrast to an analogous enzyme from a Pseudomonas. ${ }^{1}$ ' Incubation of the Flavobacterium enzyme with 1,10-phenanthroline at $50^{\circ} \mathrm{C}$ resulted in a complete loss of activity though the chelator affected the enzyme very weakly at $30^{\circ} \mathrm{C}$. The activity lost was restored not only by incubation with $\mathrm{Zn}^{2+}$ or $\mathrm{Co}^{2+}$ but also by incubation without the addition of divalent cations. If the binding of 1,10-phenanthroline to the enzyme produced inactivation and if reactivation was due to dissociation of the reagent from the enzyme, reactivation must be observed not only with $\mathrm{Zn}^{3+}$ or $\mathrm{Co}^{2+}$ but also with $\mathrm{Fe}^{3+}$ or other cations which can form complexes with 1,10 phenanthroline. As described above, the 1,10phenanthroline-treated enzyme was specifically reactivated with $\mathrm{Zn}^{2+}$ or $\mathrm{Co}^{2+}$. The fact that the apparently spontaneous reactivation was prevented by the addition of $10 \mu \mathrm{M}$ EDTA suggests the presence of active cations which contaminated the enzyme solution. It seems difficult to assume that EDTA specifically prevents the dissociation of the enzyme-bound 1,10-phenanthroline. Thus, we believe that the 1,10-phenanthroline-treated enzyme was the apoenzyme of guanidinoacetate amidinohydrolase. 
In the previous paper ${ }^{1)}$ we reported on the properties of crystalline guanidinoacetate amidinohydrolase from Pseudomonas sp. ATCC 14676. The molecular weight of the Flavobacterium enzyme was estimated to be 271,000 compared to 163,000 , the value for the Pseudomonas enzyme. Both enzymes are composed of four subunits of identical molecular weights. The Flavobacterium enzyme can hydrolyze 3guanidinopropionate and 4-guanidinobutyrate at lower rates, while the Pseudomonas enzyme is highly specific for guanidinoacetate. Unlike the $\mathrm{Mn}^{2+}$ dependent Pseudomonas enzyme, the apoenzyme of Flavobacterium guanidinoacetate amidinohydrolase was activated with $\mathrm{Zn}^{2+}$ or $\mathrm{Co}^{2+}$. Guanidinosuccinate amidinohydrolase from Pseudomonas, chlororaphis ${ }^{12}$, and Bacillus L-arginase ${ }^{13}$ were reported to be activated with $\mathrm{Co}^{2+}$, while $\mathrm{Zn}^{2+}$ has not been reported as a specific activator of amidinohydrolases. The guanidinoacetate amidinohydrolase from Flavobacterium shares features in common with the analogous Pseudomonas enzyme: a relatively high value of $K m$ for substrate, an alkaline optimal $\mathrm{pH}$ and strong inhibition by PCMB.

Both Pseudomonas and Flavobacterium guanidinoacetate amidinohydrolases are induced by guanidinoacetate. We have observed that 4-guanidinobutyrate induces 4-guanidinobutyrate amidinohydrolase in Flavobacterium GE-1, as well as in Pseudomonas sp. ATCC 14676. Although guanidinoacetate amidinohydrolase from the strain of Flavobacterium exhibits weak activity toward 4-guanidinobutyrate, a crude preparation of 4-guanidinobutyrate amidinohydrolase from the same organism does not exhibit guanidinoacetate amidinohydrolase activity (unpublished observation). Although these observations suggest that the two guanidinoacetate amidinohydrolases play the same role in both organisms, this paper demonstrated significant differences in molecular weight, subunit size and substrate specificity. Thus, the two enzymes may be an example of biochemical diversity among analogous enzymes.

Acknowledgement. We thank Dr. Kenji Soda for valuable advice and ultracentrifugal analysis.' We also thank Dr. Hidehiko Tanaka for stimulating discussions and encouragement.

\section{REFERENCES}

1) T. Yorifuji, H. Tamai and H. Usami, Agric. Biol. Chem., 41, 959 (1977).

2) H. Tamai, H. Usami and T. Yorifuji, ibid., 42, 1295 (1978).

3) H. Rosenberg, A. H. Ennor and J. F. Morrison, Biochem. J., 63, 153 (1956).

4) T. Yorifuji, K. Ogata and K. Soda, J. Biol. Chem, 246, 5085 (1971).

5) R. M. Archibald, ibid., 157, 507 (1945).

6) O. H. Lowry, N. J. Rosebrough, A. L. Farr and A. J. Randall, ibid., 193, 265 (1951).

7) H. K. Schachman, Biochemistry, 2, 887 (1963).

8) G. E. Perlman and L. G. Longworth, J. Am. Chem. Soc., 70, 2719 (1948).

9) J. L. Hedrick and A. J. Smith, Arch. Biochem. Biophys., 126, 155 (1968).

10) K. Weber and M. Osborn, J. Biol. Chem., 244, 4406 (1969).

11) S. Moore and W. H. Stein, ibid., 211, 907 (1954).

12) S. Milstein and P. Goldman, ibid., 247, 6280 (1972).

13) N. Nakamura, M. Fujita and K. Kimura, Agric. Biol. Chem., 37, 2827 (1973). 